\title{
Pengabdian Masyarakat Bagi Pokdarwis Krenomata RW 3 Kelurahan Kemirirejo, Kota Magelang Untuk Merintis Kampung Wisata Edukasi
}

\author{
Anissa Hakim Purwantini, Farida \\ Fakultas Ekonomi dan Bisnis Universitas Muhammadiyah Magelang \\ Email: anissa.hakim@ummgl.ac.id
}

\begin{abstract}
Kampung Rukun Warga (RW) 03 Kelurahan Kemirirejo, Central Magelang Regency, Magelang City has various potentials to be developed as a pilot educational tourism village. The enthusiasm of the community can also be seen with the formation of a tourism awareness group (pokdarwis). However, the management of Pokdarwis Krenomata in RW 03 still does not understand the roles and functions as well as how the strategies and next development steps are to realize an Educational Tourism Village. Therefore, training and mentoring are needed to optimize the role and function of Pokdarwis in order to formulate the right strategy for realizing a tourist village. The purpose of this service is to provide an understanding of the role and function of pokdarwis, mentoring the concept of a tourism village, and business management consisting of marketing strategies, financial records and simple bookkeeping, and charms. This service provides skills and knowledge to pokdarwis administrators and members in pioneering educational tourism villages. The formation of this educational tourism village is expected to encourage the economic independence of the urban community, especially the City of Magelang.
\end{abstract}

Keywords: Pokdarwis Krenomata, Educational Tourism Village, Participatory Village Assessment

\section{Pendahuluan}

Kampung RW 03 merupakan salah satu kampung yang termasuk dalam wilayah Kelurahan Kemirirejo, Kecamatan Magelang Selatan, Kota Magelang. Kampung RW 03 terdiri dari tujuh Rukun Tetangga dan memiliki penduduk sekitar 120 KK. Secara geografis, lokasi kampung RW 03 cukup strategis karena hanya berjarak sekitar $0,9 \mathrm{~km}$ dari pusat kota Alun-Alun dan berbatasan dengan RSUD Tidar serta pusat perbelanjaan pecinan. 
Kampung RW 03 memiliki banyak prestasi dan potensi untuk dikembangkan. Diantaranya juara 1 lomba K3 dan bantaran sungai sejak tahun 2016 sampai dengan 2018. Selain itu, RW 03 juga menjadi kampung layak anak serta tersedia fasilitas Ruang Terbuka Hijau (RTH) disertai taman bermain dan perpustakaan untuk membaca anak-anak. Dalam segi historis, di kampung RW 03 terdapat jejak sejarah tower sirine peninggalan zaman Belanda yang terletak di atas irigasi kali kota. Selain itu, terdapat pula rumah bibit dan bank sampah untuk pemanfaatan kerajinan dari barang bekas. Fasilitas umum seperti MCK juga tersedia bagi warga masyarakat RW 03 Kelurahan Kemirirejo.

Potensi sumber daya tersebut menjadikan kampung RW 03 ditunjuk oleh Kelurahan Kemirirejo sebagai perwakilan rintisan Kampung Wisata yang diselenggarakan oleh Dinas Pemuda Olahraga dan Pariwisata Kota Magelang pada tanggal 20 November 2018. Sebagai langkah awal, telah dibentuk Kelompok Sadar Wisata (Pokdarwis) sebagai wadah yang diharapkan dapat menjadi pioneer dalam pengembangan rintisan kampung wisata edukasi.

Alasan menjadikan kampung RW 03 Kelurahan Kemirirejo sebagai kampung wisata edukasi anak adalah untuk mengoptimalkan potensi yang ada menjadi peluang ekonomi kreatif yang dapat memberikan sumber penghasilan bagi warga. Selain itu predikat RW layak anak di RW 3 menjadi modal dasar yang bagus untuk dikembangkan. Selama ini, wisata edukasi sebagian besar berada di kawasan pedesaan berbasis pendidikan alam. Masih sangat jarang objek wisata edukasi di daerah perkotaan. Berdasarkan analisis berbagai macam potensi yang dimiliki kampung RW 03 yang telah dipaparkan sebelumnya, maka Pokdarwis Krenomata berinisiatif untuk merintis kampung wisata edukasi anak. Tujuan kampung wisata edukasi anak ini adalah menambah pengetahuan dan wawasan bagi wisatawan 
khususnya usia sekolah agar lebih peka terhadap lingkungan dan budaya yang saat ini mulai luntur.

Konsep pengembangan kampung berkelanjutan pada kawasan perkotaan, menjadi hal penting. Kampung diharapkan dapat menjadi konsep alternatif untuk menjaga dan mengembangkan kawasan permukiman yang berkelanjutan meliputi bidang ekonomi dan lingkungan. Rintisan kampung wisata edukasi di RW 03 Kelurahan Kemirirejo merupakan perwujudan dari pengembangan kampung berkelanjutan. Tersedianya potensi yang ada di RW 03 telah memenuhi indikator dalam pengembangan kampung berkelanjutan menurut yaitu: peluang ekonomi, pemerataan, partisipasi masyarakat, ekologi, ruang kreatif, atraksi, keterjangkauan dan keberadaan lokasi yang layak. ${ }^{1}$

Pariwisata melalui Community Based Tourism (CBT) mampu menjadi pendongkrak kemajuan ekonomi kerakyatan. Konsep pengembangan desa wisata yang ada telah terbukti mampu meningkatkan kesejahteraan sosial masyarakat lokal, rasa kepedulian terhadap lingkungan yang semakin baik, serta memotivasi masyarakat untuk bangga dengan identitas budaya yang dimiliki. ${ }^{2}$ Dengan demikian, adanya rintisan kampung wisata edukasi anak di wilayah pemukiman kampung RW 03 Kelurahan Kemirirejo diharapkan dapat menjadi pendorong kemandirian ekonomi rakyat sehingga peningkatan kesejahteraan masyarakat dapat terwujud.

Antusiasme warga terhadap pengembangan rintisan kampung wisata edukasi anak begitu besar. Hal ini diwujudkan dengan telah terbentuknya sebuah kelompok sadar wisata (pokdarwis) Krenomata (kreatif, inovatif, mandiri dan tangguh). Akan tetapi, terdapat permasalahan dalam lembaga tersebut. Secara garis besar, permasalahan yang dihadapi mitra adalah:

${ }^{1}$ Arlis Hardiyanto, "Penataan Kawasan Semanggi Surakarta Sebagai Kampung Ramah Anak". Publikasi Ilmiah. Program Studi Arsitektur Fakultas Teknik, Universitas Muhammadiyah Surakarta (2016)

${ }^{2}$ Hary Hermawan, "Dampak Pengembangan Desa Wisata Nglanggeran Terhadap Ekonomi Masyarakat Lokal”. Jurnal Pariwisata, Vol. 3, No.1 (2016):105-117 
Pertama, masih kurangnya kualitas sumber daya manusia (SDM) baik di dalam kelembagaan maupun pengelolaan rintisan kampung wisata edukasi anak. Para pengurus dan anggota pokdarwis Krenomata belum memahami dengan baik fungsi dan peran mereka untuk mewujudkan rintisan kampung wisata edukasi anak. Di sisi lain, segala potensi yang tersedia menjadikan kampung ini memiliki daya tarik pariwisata yang menarik untuk dikembangkan. Sehingga penguatan kelembagaan serta pematangan konsep kampung wisata perlu dilakukan guna terciptanya rintisan kampung wisata edukasi anak. Lebih lanjut, untuk dapat mewujudkan sebuah kampung wisata edukasi anak yang sukses maka perlu bekal manajemen usaha. Manajemen usaha tersebut meliputi managemen keuangan dan managemen pemasaran. Lebih lanjut, untuk memenuhi sapta pesona pariwisata maka diperlukan cinderamata yang unik dan khas.

Permasalahan kedua yaitu promosi dan pemasaran yang efektif. Pengurus Pokdarwis Krenomata masih memiliki kesulitan dan keterbatasan dalam menentukan strategi pemasaran yang efektif. Sehingga perlu diadakan pelatihan dan pendampingan pemasaran serta pemanfaatan internet dan media sosial sebagai sarana promosi. Fenomena saat ini di masyarakat yaitu senang mengunggah foto di berbagai media sosial. Hal ini dapat dijadikan kesempatan baik untuk mengembangkan dan mempromosikan kampung RW 03 sebagai salah satu daerah tujuan wisata edukasi yang menarik dan terjangkau secara finansial.

Tujuan pengabdian ini adalah memberikan pemahaman, pelatihan dan pendampingan kepada pengurus dan anggota Pokdarwis Krenomata di Kampung RW 03 Kelurahan Kemirirejo, Kecamatan Magelang Tengah, Kota Magelang sehingga permasalahan yang dihadapi mitra yaitu kualitas SDM dan pemasaran dapat teratasi. 


\section{Metode}

Pelaksanaan pengabdian ini menggunakan metode Participatory Rural Appraisal (PRA). Teknik PRA sebagai sarana untuk melibatkan masyarakat dalam proses pembangunan. Oleh karena itu, kesesuaian dan ketepatgunaan program bagi masyarakat diharapkan dapat tercapai sehingga keberlanjutan program lebih terjamin. ${ }^{3}$ Metode PRA ini merupakan pendekatan dalam proses pemberdayaan dan peningkatan partispasi masyarakat yang menjadikan warga sebagai perencana dan pelaksana program sehingga bukan hanya sekedar objek pengabdian saja. Tahapan pendekatan yang dilakukan meliputi:

1. Focus Group Discussion dengan pengurus pokdarwis dan aparat pemerintah setempat guna mengidentifikasi permasalahan yang terjadi dan menentukan program yang akan dijalankan sesuai dengan prioritas masalah.

2. Pelaksanaan program dengan mendorong masyarakat untuk terlibat secara aktif dan kreatif sehingga dapat memunculkan solusi tepat berdasarkan kebutuhan. Hal ini diimplementasikan melalui kegiatan sosialisasi, pelatihan dan pendampingan pokdarwis Krenomata dalam merintis kampung wisata edukasi.

3. Evaluasi kegiatan guna mengetahui masukan dari mitra serta melakukan penilaian terhadap keberhasilan kegiatan pengabdian dan rencana tindak lanjut. Evaluasi dilakukan dengan menyebarkan kuesioner sehingga penilaian dapat terukur.

Kegiatan pengabdian masyarakat ini dilaksanakan di kampung RW 3 Kelurahan Kemirirejo, Kecamatan Magelang Tengah, Kota Magelang, Jawa Tengah. Pengabdian berlangsung dalam kurun waktu empat bulan terhitung

${ }^{3}$ Asep Supriatna,"Relevansi Metode Participatory Rural Appraisal Dalam Mendukung Implementasi Undang-Undang Pemerintahan Desa". Jurnal Lingkar Widyaswara Edisi 1 No. 1 (Maret 2014):39-45. 
sejak Januari sampai April 2019. Mitra yang terlibat adalah pengurus Pokdarwis Krenomata dengan jumlah 5-10 orang.

\section{Hasil dan Diskusi}

Program Kemitraan Universitas bagi Pokdarwis Krenomata RW 3 Kelurahan Kemirirejo dilaksanakan secara bertahap mulai dari prapelaksanaan, pelaksanaan dan pascapelaksanaan.

1. Prapelaksanaan

Pada tahap prapelaksanaan dilakukan beberapa kegiatan sebagai langkah persiapan sebelum pelaksanaan pengabdian. Kegiatan tersebut antara lain yaitu: (1). Rapat koordinasi tim pelaksana pengabdian masyarakat untuk menyusun timeline dan keperluan korespondensi; (2). Mengurus perijinan pelaksanaan pengabdian ke pemerintah daerah setempat yaitu Kelurahan Kemirirejo dan Ketua RW 3; (3). Observasi dan wawancara pengurus pokdarwis untuk analisis awal; (4)Menyusun job desk dan membagi job desk kepada anggota kelompok; (5) Menyiapkan materi untuk kegiatan pengabdian; (6) Menyiapkan peralatan dan bahan yang dibutuhkan dalam proses pelaksanaan kegiatan pengabdian.

2. Pelaksanaan

Tim pelaksana pengabdian masyarakat telah melaksanakan pemberdayaan masyarakat meliputi sosialisasi, pelatihan dan pendampingan Pokdarwis Krenomata RW 3 Kelurahan Kemirirejo, Kota Magelang untuk merintis kampung wisata edukasi. Tim pengabdian masyarakat bersama dengan pokdarwis merumuskan konsep "Kampung Pintar" sebagai kampung wisata edukasi dengan icon branding tower sirine "bengung". Kegiatan pengabdian ini berlangsung sekitar 4 bulan terhitung Januari sampai April 2019. Pelaksanaan kegiatan secara rinci dapat dilihat pada Tabel 1. berikut. 
Tabel 1. Pelaksanaan Pengabdian Masyarakat bagi Pokdarwis Krenomata

\begin{tabular}{|c|c|c|c|c|}
\hline No. & Tanggal & Kegiatan dan Hasil & Peserta & Tempat \\
\hline 1. & $06 / 02 / 2019$ & $\begin{array}{l}\text { Focus Group Discussion untuk } \\
\text { mengidentifikasi permasalahan } \\
\text { yang ada di pokdarwis. } \\
\text { Hasilnya adalah materi } \\
\text { pengabdian akan fokus pada } \\
\text { penguatan kelembagaan, } \\
\text { manajemen usaha yang terdiri } \\
\text { dari pemasaran r dan } \\
\text { pembukuan, serta sapta } \\
\text { pesona. }\end{array}$ & $\begin{array}{l}\text { Pengurus } \\
\text { Pokdarwis } \\
\text { Krenomata }\end{array}$ & $\begin{array}{l}\text { Rumah Ketua } \\
\text { Pokdarwis }\end{array}$ \\
\hline 2. & $21 / 02 / 2019$ & $\begin{array}{l}\text { Rakor untuk menyusun } \\
\text { AD/ART Pokdarwis Krenomata } \\
\text { RW } \\
\text { S Kelurahan Kemirirejo }\end{array}$ & $\begin{array}{l}\text { Pengurus } \\
\text { Pokdarwis } \\
\text { Krenomata }\end{array}$ & $\begin{array}{l}\text { Rumah Ketua } \\
\text { Pokdarwis }\end{array}$ \\
\hline 3. & $01 / 03 / 2019$ & $\begin{array}{l}\text { Pelatihan untuk peningkatan } \\
\text { kualitas SDM pengurus } \\
\text { Pokdarwis Krenomata. Materi } \\
\text { terdiri dari penguatan } \\
\text { kelembagaan (fungsi dan peran } \\
\text { pokdarwis), konsep rintisan } \\
\text { kampung wisata (berdasar } \\
\text { analisis SWOT), pembukuan } \\
\text { dan administrasi sederhana, } \\
\text { serta pemasaran. }\end{array}$ & $\begin{array}{l}\text { Perwakilan } \\
\text { pengurus } \\
\text { pokdarwis }\end{array}$ & $\begin{array}{l}\text { Laboratorium } \\
\text { Internet dan } \\
\text { Komputer } \\
\text { FEB UMMgl }\end{array}$ \\
\hline 4. & $5 / 03 / 2019$ & $\begin{array}{l}\text { Pendampingan pembuatan } \\
\text { gapura dengan icon bunga } \\
\text { matahari dari daur ulang botol } \\
\text { plastik bekas. }\end{array}$ & $\begin{array}{l}\text { Anggota } \\
\text { Pokdarwis }\end{array}$ & $\begin{array}{l}\text { RW } 3 \\
\text { Kelurahan } \\
\text { Kemirirejo }\end{array}$ \\
\hline 5. & $13 / 03 / 2019$ & $\begin{array}{l}\text { Sosialisasi sapta } \text { pesona } \\
\text { pariwisata dan pelatihan } \\
\text { pembuatan cinderamata khas } \\
\text { dari daur ulang sampah. }\end{array}$ & $\begin{array}{l}\text { Ibu-ibu } \\
\text { PKK RW } 3\end{array}$ & $\begin{array}{l}\text { Balai RW } 3 \\
\text { Kelurahan } \\
\text { Kemirirejo }\end{array}$ \\
\hline 6. & $6 / 04 / 2019$ & $\begin{array}{l}\text { Pendampingan pembuatan } \\
\text { pembukuan keuangan dan } \\
\text { administrasi sederhana serta } \\
\text { perbaikan fasilitas Ruang } \\
\text { Terbuka Hijau. }\end{array}$ & $\begin{array}{l}\text { Pengurus } \\
\text { Pokdarwis }\end{array}$ & $\begin{array}{l}\text { RW } 3 \\
\text { Kelurahan } \\
\text { Kemirirejo }\end{array}$ \\
\hline 7. & $13 / 04 / 2019$ & $\begin{array}{l}\text { Pendampingan } r \text { perincian } \\
\text { konsep rintisan kampung } \\
\text { wisata serta penyelesaian } \\
\text { pembuatan pagar selamat } \\
\text { datang yang berlokasi di atas } \\
\text { jembatan. }\end{array}$ & $\begin{array}{l}\text { Pengurus } \\
\text { Pokdarwis }\end{array}$ & $\begin{array}{l}\text { RW } 3 \\
\text { Kelurahan } \\
\text { Kemirirejo }\end{array}$ \\
\hline
\end{tabular}

Pengabdian Masyarakat Bagi Pokdarwis Krenomata RW 3 Kelurahan Kemirirejo, Kota Magelang Untuk Merintis Kampung Wista Edukasi 


\begin{tabular}{|c|c|l|l|l|}
\hline No. & Tanggal & \multicolumn{1}{|c|}{ Kegiatan dan Hasil } & Peserta & \multicolumn{1}{c|}{ Tempat } \\
\hline 8. & $18 / 4 / 2019$ & $\begin{array}{l}\text { Evaluasi kegiatan selama } \\
\text { pengabdian berlangsung serta } \\
\text { penyampaian pesan dan kesan. } \\
\text { Penutupan Pengurus } \\
\text { pengabdian. }\end{array}$ & Rumah Ketua \\
Pokdarwis & Pokdarwis \\
\hline
\end{tabular}

Sumber: Dokumentasi Pelaksanaan Lapangan, 2019

3. Pascapelaksanaan

Tahap pascapelaksanaan pengabdian ini dilakukan dengan mengevaluasi program secara menyeluruh. Metode evaluasi yang dilakukan yaitu melalui kuesioner dan testimoni. Kuesioner sebelum dan sesudah dilaksanakannya kegiatan bertujuan untuk menilai tingkat pemahaman materi yang disampaikan oleh tim pelaksana kepada sasaran program. Testimoni sebelum dan sesudah dilaksanakan pengabdian bertujuan untuk mengetahui keberhasilan program. Tingkat kebermanfaatan kegiatan diungkapkan dengan adanya testimoni kesan dan pesan dari pengurus pokdarwis. Indikator keberhasilan Program Kemitraan Universitas ini adalah dapat menanamkan kesadaran wisata dan terciptanya rintisan kampung wisata edukasi di RW 3 Kelurahan Kemirirejo.

\section{Pembahasan}

\section{Penguatan Kelembagaan Pokdarwis}

Kegiatan yang dilakukan pertama kali adalah penguatan kelembagaan bagi Pokdarwis Krenomata dengan menyusun AD/ART dan sosialisasi fungsi, tugas dan peran pengurus pokdarwis. Sebelum adanya pengabdian, pokdarwis yang telah terbentuk hanya mempunyai struktur organisasi saja. Para pengurus belum memahami secara mendetail tugas, wewenang dan fungsi dari masing-masing pengurus sesuai bidangnya. Agar pengurus dapat menjalankan perannya dengan optimal dan tidak mengalami kebingungan, maka pada sesi pertama dilaksanakan 
penyampaian materi tentang tugas, fungsi dan wewenang serta peran pengurus pokdarwis secara rinci sesuai yang ada pada struktur organisasi.

Pada sesi pertama ini disampaikan pula Achieve Motivation Training dengan memutarkan video mengenai kampung lainnya yang berhasil menjadi kampung wisata edukasi. Diantaranya yaitu Kampung 3G yang ada di Jawa Timur. Semula perkampungan ini identik dengan kumuh dan sering banjir. Berkat peran dari ketua RT setempat dan dukungan tokoh masyarakat serta kesadaran masyarakat, kini Kampung 3G telah berhasil mendapatkan omset 300an juta per bulan dari pendapatan kampung wisata. Kisah ini berhasil memotivasi para pengurus Pokdarwis Krenomata untuk semakin mantab merintis kampung wisata. Diharapkan mereka tidak pernah menyerah dan gampang putus asa dalam mewujudkan visi, misi dan tujuannya.

\section{Konsep Rintisan Kampung Wisata Edukasi}

Sesi berikutnya adalah brainstorming dan diskusi bersama pengurus Pokdarwis. Diskusi tersebut mencakup bagaimana caranya agar dapat mengembangkan rintisan kampung wisata edukasi. Langkah pertama yang dilakukan adalah analisis SWOT (Strength, Weakness, Opportunity, Thread). Berdasarkan pada diskusi diperoleh hasil sebagai berikut:

a) Kekuatan:

1) Terdapat fasilitas RTH (Ruang Terbuka Hijau), perpustakaan, MCK umum dan bank sampah sebagai pendukung rintisan kampung wisata.

2) Terdapat tower sirine "bengung" sebagai objek sejarah

3) Memiliki hubungan baik dengan pemerintah karena sering mewakili berbagai macam lomba, sehingga memudahkan koordinasi.

b) Kelemahan:

1) Tempat parkir yang kurang luas, hanya tersedia di badan jalan saja. 
2) Arus air irigasi kota yang digunakan untuk tubing tidak setiap hari mengalir.

3) Tidak memiliki lahan terbuka yang luas dan sebagian besar pemukiman padat penduduk dengan gang sempit.

c) Peluang:

1) Belum banyak kampung wisata edukasi di daerah Kota Magelang sehingga memiliki peluang besar untuk dikembangkan

2) Banyaknya PAUD, kelompok bermain, dan TK serta SD di wilayah sekitar Kota Magelang sebagai subjek wisata.

3) Lokasi yang strategis di tengah pusat kota memudahkan akses lokasi.

d) Ancaman:

Kurangnya kesadaran masyarakat dalam pentingnya menjaga sapta pesona, seperti menjemur baju di pinggir kali yang akan mengganggu pemandangan.

Berdasarkan pada analisis SWOT tersebut maka disusun konsep rintisan kampung wisata yaitu wisata edukasi yang memberikan wawasan, ketrampilan dan pengetahuan baru kepada pengunjung baik dari bidang sejarah, ilmu alam, seni dan budaya. Kampung wisata edukasi ini diperuntukkan khususnya bagi TK sampai SMP. Tetapi tidak menutup kemungkinan juga untuk semua kalangan usia yang tertarik dan berminat untuk menambah wawasan dan pengetahuan.

Berdasarkan pada identifikasi pada analisis SWOT yang telah didiskusikan bersama antara pengurus pokdarwis Krenomata dan tim pengabdian UMMagelang, maka dirumuskan 4 pos wahana yang nantinya akan menjadi produk yang ditawarkan kepada pengunjung antara lain yaitu:

1) "Sejarah yang Tak Terlupakan"

Disini akan disajikan cerita sejarah dari tower sirine bengung agar generasi mengetahui peninggalan sejarah terutama yang terdapat di 
daerah sekitarnya. Melalui wahana ini seacra tidak langsung mendidik pengunjung agar lebih mencintai tanah air dan menghargai jasa para pahlawan pejuang kemerdekaan. Selain itu, akan dipaparkan foto Kampung RW 3 tempo dulu dan perubahannya sampai masa kini.

2) "Sayangi Bumiku"

Melalui pos ini pengunjung akan diberikan pengalaman menonton secara langsung cara pembuatan berbagai produk olahan daur ulang sampah yang menarik. Sebelumnya, pengunjung akan disuguhi film pendek tentang efek merugikan tumpukan sampah. Dengan cara ini dapat mengedukasi pengunjung agar mengolah sampah dengan bijak untuk masa depan bumi yang lebih baik.

3) "Alam Semestaku"

Dalam wahana ini terbagi dalam flora, fauna, dan tata surya. Flora yaitu dunia tumbuhan yang terdiri dari tumbuhan buah, bunga dan emponempon. Tumbuhan ini ditanam di sekitar bantaran sungai, rumah warga dan disekitar Ruang Terbuka Hijau. Diharapkan pengunjung dapat melihat secara langsung pohon yang menghasilkan buah, karena banyak yang tidak mengetahui rupa pohonnya. Fauna dan tata surya, dunia hewan dan benda angkasa luar ini hadir dalam bentuk gambar yang ditempel di sekitaran Ruang Terbuka Hijau dan dinding-dinding bangunan sekitar. Fauna terdiri dari aneka hewan yang hidup di darat dan laut. Sedangkan tata surya terdiri dari berbagai macam benda angkasa di tata surya kita.

4) “Dolanan Tempoe Doeloe”

Berisi berbagai macam permainan tradisional seperti dakon, bola bekel, sudah mandah, egrang bambu dan batok kelapa serta berbagai jenis permainan tradisional lainnya. Salah satu permainan unik yang akan ditawarkan adalah tubing kali dengan menggunakan ban besar. Adanya pos wahana ini bertujuan untuk mengenalkan kepada pengunjung 
terutama anak-anak akan seru dan menariknya permainan jaman dulu. Sehingga nantinya diharapkan anak-anak masa kini tidak terlalu lama bermain games di gadget yang akan menimbulkan permasalahan kesehatan dan psikis.
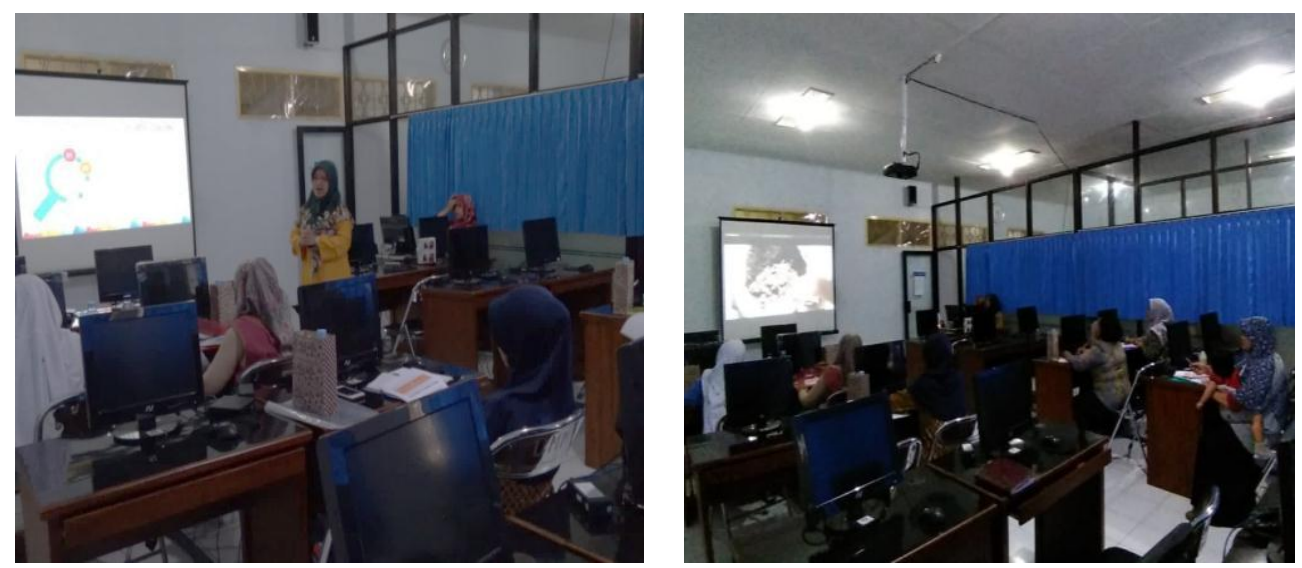

\section{Gambar 1. Pelatihan Peningkatan Kualitas SDM Pokdarwis Krenomata (Sumber: Dokumentasi Pengabdian, 2019)}

\section{Pengelolaan Manajemen Usaha}

Pelatihan dan pendampingan selanjutnya adalah mengenai pengelolaan manajemen usaha yang secara spesifik terdiri dari pencatatan keuangan sederhana dan administrasi serta pemasaran. Materi mengenai pemasaran dan promosi disampaikan oleh Ibu Anissa Hakim Purwantini, S.,E., M.Sc sedangkan terkait pembukuan dan akuntansi sederhana disampaikan oleh Ibu Farida, M.Sc., Ak. Sesi ini memaparkan langkahlangkah dalam pemasaran yaitu:

1) Identifikasi Produk

Produk dalam kampung wisata merupakan pengalaman total pengunjung dari apa yang dilihat, dilakukan dan dibeli. Potensi yang dimiliki kampung RW 3 adalah adanya tower bengung, bank sampah, Ruang Terbuka Hijau ramah anak, perpustakaan, bantaran sungai, dan banyak warga yang menjual makanan tradisional. Berdasarkan potensi 
tersebut, maka produk yang akan ditawarkan berupa wisata edukasi anak yang terdiri dari pelayanan jasa dan penyediaan cinderamata dari hasil daur ulang (produk bank sampah) serta aneka jajanan tradisonal untuk pengunjung.

2) Merumuskan Unic Selling Point (USP)

USP merupakan keunikan yang akan dijual kepada pasar yang merupakan alasan mengapa pengunjung akan datang ke kampung wisata. Berdasarkan pada identifikasi produk, maka keunikan yang akan dijual ke pasar adalah peninggalan sejarah tower sirine "Bengung" sebagai wisata sejarah. Selain itu adanya produk daur ulang dari bank sampah dapat dijadikan sebagai wisata edukasi mengenai cara pembuatan tersebut. Contoh produk daur ulang dari sampah botol plastik adalah bunga matahari yang dijadikan ikon di pagar selamat datang.

3) Menetapkan Target Pasar dan Positionning

Target pasar kampung wisata edukasi ini disesuaikan dengan karakteristik produk dan USP yang telah ditetapkan. Oleh karena itu, target pasar kampung wisata edukasi ini difokuskan pada segmen pelajar mulai dari siswa Taman Kanak-Kanak sampai dengan SMP. Secara umum segmen pasar kampung wisata ini cukup luas, karena menyuguhkan berbagai jenis edukasi untuk segala usia. Lebih lanjut, positionning kampung wisata ini adalah sebagai sentra wisata edukasi di Magelang.

4) Membangun Identitas (branding) yang Menarik

Identitas merk diperlukan agar kampung wisata edukasi RW 3 dapat dibedakan dengan yang lain dan dapat mudah diingat oleh pasar. 
Terdapat enam hal penting yang harus diperhatikan dalam membangun identitas/merk ini antara lain yaitu4:

a) Memorability; merk harus mudah diingat, mudah dikenal, mudah terbaca, mudah diperhatikan dan menjadi pusat perhatian.

b) Meaningfullness; merk harus memiliki arti dan esensi yang berhubungan dengan produk.

c) Likebility; merk harus berkesan secara estetika (eye-catching).

d) Transferability; merk harus dapat disesuaikan dengan bahasa atau kebiasaan segmen pasar.

e) Adaptability; merek harus fleksibel atau cocok ditempatkan pada segala media, kondisi atau situasi.

f) Protectability; merek jangan sampai diimitasi atau diduplikasi, oleh karena itu harus didaftarkan secara legal.

Dengan mempertimbangkan hal tersebut, maka diputuskan brand untuk kampung wisata edukasi ini adalah "Kampung Pintar" dengan slogan sahabat petualang dan belajar.

5) Membangun produk

Komposisi produk kampung wisata ini terdiri dari tiga macam yaitu produk fisik, paket wisata dan program. Produk fisik berupa peninggalan sejarah (tower bengung), berbagai macam permainan tradisional, dan fasilitas pada Ruang Terbuka Hijau. Sedangkan paket wisata yaitu terdiri dari gabungan dari beberapa tujuan kunjungan dengan satu harga tertentu yang disajikan dari gabungan produk yang ditawarkan. Terdiri dari paket outbond mini yaitu permainan tradisional dan tubing, paket "aku makin pintar" yaitu penjelasan sejarah, flora, fauna, tata surya serta pelatihan daur ulang sampah.

4 Kevin Lane Keller. Strategic Brand Management Building Measuring and Managing Brand Equity 4th edition. (2013). USA, Pearson Education. 
Selanjutnya, untuk program merupakan produk di saat event tertentu seperti Hari Anak Nasional, Hari Kemerdekaan, Hari Bumi, dan lain-lain.

6) Menetapkan harga dan membangun saluran pemasaran.

Penetapan harga tiket masuk dan harga per paket tidak mudah dilakukan. Penghitungan harga tiket perlu mempertimbangkan berbagai macam faktor dan komponen seperti macam-macam biaya produk. Kampung wisata edukasi ini belum sempurna dalam infrastruktur dan hanya sebagian kecil yang sudah terealisasi karena baru dalam tahap rintisan. Sehingga dalam penetapan harga mengacu pada penetapan harga rendah diawal yang bertujuan untuk merangsang kunjungan. Selanjutnya harga akan dinaikkan sampai pada posisi harga normal yang akan ditawarkan secara regular. Sementara untuk harga promosi dan pengenalan ditetapkan sebesar Rp2.000rb per orang.

7) Melakukan promosi pemasaran. Promosi pemasaran dilakukan secara online maupun offline. Pemasaran online dengan membuat akun media social seperti facebook, instagram dan melalui WhatsApp. Cara ini ditempuh agar promosi dapat berjalan lebih efektif. Promosi offline dengan mencetak leafleat dan stiker.
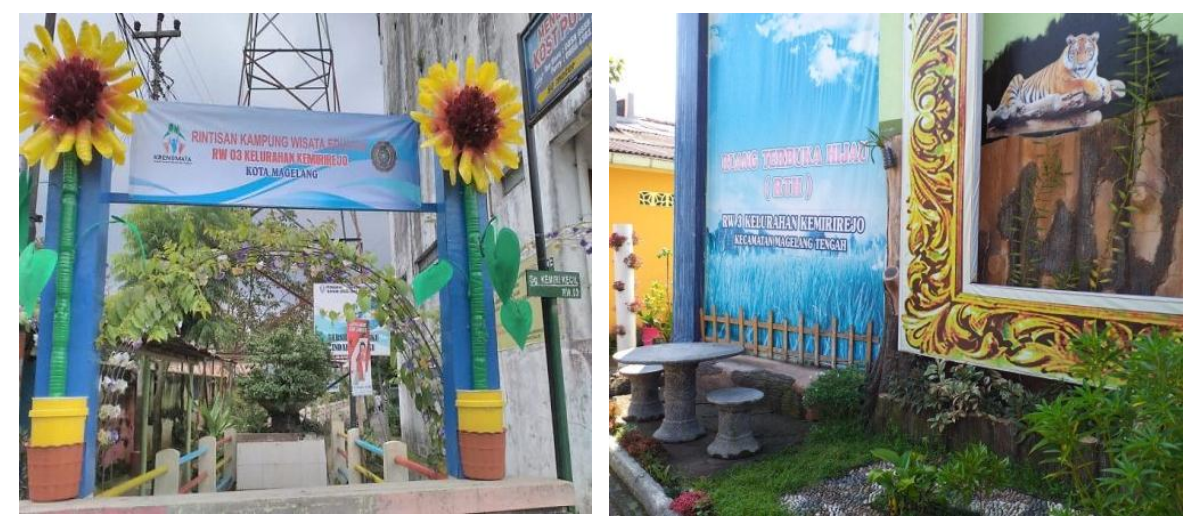

\section{Gambar 2. Rintisan Kampung Wisata Edukasi di RW 3 Kelurahan} Kemirirejo (Sumber: Dokumentasi Pengabdian, 2019) 


\section{Sosialisasi Sapta Pesona dan Pelatihan Cinderamata}

Program kegiatan terakhir yaitu sosialisasi Sapta Pesona oleh Ibu Farida, M.Si, Ak, CA. Peserta adalah pengurus pokdarwis dan ibu-ibu PKK RW 3 Kelurahan Kemirirejo. Sapta pesona ini penting disampaikan karena kedepannya ibu-ibu PKK akan menjadi pelayan bagi pengunjung/wisatawan sehingga penanaman sadar wisata krusial dilakukan. Sapta pesona terdiri dari 7 unsur yaitu Keamanan, Ketertiban, Kebersihan, Kesejukan, Keindahan, Keramahan, dan Kenangan. Dengan teriptanya suasana dan kondisi di objek wisata yang menarik, nyaman, bersih diharapkan wisatawan akan merasa senang, puas dan mempunyai pengalaman dan kenangan indah dalam kunjungan wisatanya. Sapta Pesona yang perlu diwujudkan antara lain yaitu:

1) Aman

Warga masyarakat harus menciptakan suasana aman dan tenteram sehingga pengunjung merasa terlindungi. Hal yang harus diperhatikan adalah keamanan tempat parkir dan wahana permainan seperti tubing dan egrang.

2) Tertib

Masyarakat di kampung RW 3 Kemirirejo harus mampu menciptakan suasana yang teratur, rapi dan lancar serta menunjukkan disiplin yang tinggi dalam semua segi kehidupan masyarakat. Misalnya pelayanan kepada pengunjung secara baik dan tepat, penataan kendaraan bermotor yang rapi, memberikan informasi yang benar dan tidak membingungkan pengunjung.

3) Bersih

Warga masyarakat harus menjaga kebersihan terutama di lingkungan sekitar rumah masing-masing karena objek wisata adalah kampung. Selain itu perlu dilakukan kerja bakti untuk menjaga kebersihan dan perawatan di tempat-tempat utama seperti bantaran sungai, RTH, dan 
bank sampah. Kebersihan fasilitas MCK juga wajib diperhatikan. Selain itu, pakaian dan penampilan petugas pelayanan harus bersih, rapi, dan tidak berbau kurang sedap.

4) Sejuk

Diharapkan semua warga turut berpartisipasi dalam menjaga kesejukan lingkungan dengan turut serta aktif memelihara kelestarian lingkungan dan hasil penghijauan yang telah dilakukan masyarakat maupun pemerintah. Secara sadar merawat tanaman baik yang ada di sekitar rumah masing-masing dan yang berada di bantaran sungai.

5) Indah

Keindahan objek wisata dapat dilihat dari berbagai sudut pandang seperti segi tata warna, tata letak, tata ruang bentuk ataupun gaya dan gerak yang serasi dan selaras, sehingga memberi kesan yang enak dan cantik untuk dilihat. Oleh karena itu perlu diperhatikan ketika ada warna cat yang sudah usang, dapat segera diperbaiki.

6) Ramah Tamah

Warga masyarakat dalam menghadapi dan melayani pengunjung harus mampu bersikap dan berperilaku akrab, sopan, murah senyum, suka membantu serta menghormati wisatawan yang berkunjung. Sikap ramah tamah ini merupakan satu daya tarik bagi wisatawan, oleh karena itu harus dapat dipelihara.

7) Kenangan

Agar pengunjung memiliki kenangan yang menyenangkan dan menarik maka perlu diperhatikan dalam pelayanan seperti fasilitas dan akomodasi yang nyaman, bersih, sehat. Makanan dan minuman yang disajikan terasa lezat dan khas sehingga dapat dijadikan ciri khas. Selain itu penyediaan cinderamata yang unik, khas, dan harga yang murah menjadi penentu kenangan tersendiri bagi wisatawan. 
Selanjutnya sesi pelatihan untuk mendukung sapta pesona wisata yaitu pembuatan cinderamata khas dari daur ulang sampah. Sampah yang banyak dihasilkan salah satunya adalah sampah plastik dari botol air mineral. Oleh karena itu, dilakukan pelatihan untuk memanfaatkan sampah ini menjadi produk yang dapat bernilai jual dan dijadikan cinderamata khas. Sejalan dengan produk yang ditawarkan di kampung wisata edukasi "Kampung Pintar" untuk melestarikan alam, maka salah satu bentuk cinderamata khas adalah pot bunga dan tanaman.

Pelatihan ini dilakukan bersama dengan ibu-ibu PKK RW 3. Bahan yang dibutuhkan sangat sederhana, yaitu botol plastik, lem tembak, spidol dan cat warna. Kunci dalam pembuatan cinderamata ini adalah inovasi dan daya kreativitas.

\section{Simpulan}

Kegiatan pengabdian masyarakat ini dapat meningkatkan pemahaman, pengetahuan dan ketrampilan pengurus Pokdarwis Krenomata RW 3 sebagai bekal untuk merintis kampung wisata edukasi di Kelurahan Kemirirejo, Kota Magelang. Peran dan fungsi pokdarwis yang berjalan lancar akan dapat membantu dalam pengelolaan dan pengembangan rintisan kampung wisata edukasi. Kejelasan konsep bisnis kampung wisata edukasi dapat digunakan untuk menyusun strategi yang tepat guna memaksimalkan potensi pariwisata. Terwujudnya kampung wisata dapat menjadi alternatif pendapatan bagi warga sekitar. Warga yang tidak memiliki pekerjaan tetap dapat memperoleh tambahan penghasilan sebagai guide maupun membuka warung jajanan serta menyediakan kerajian cinderamata khas kampung wisata edukatif anak. Sehingga dapat meningkatkan kesejahteraan dan kemandirian masyarakat melalui ekonomi kreatif di bidang pariwisata. 


\section{Referensi}

Hardiyanto, Arlis. "Penataan Kawasan Semanggi Surakarta Sebagai Kampung Ramah Anak". Publikasi Ilmiah. Program Studi Arsitektur Fakultas

Teknik, Universitas Muhammadiyah Surakarta (2016).

Hermawan, Hary. "Dampak Pengembangan Desa Wisata Nglanggeran Terhadap Ekonomi Masyarakat Lokal”. Jurnal Pariwisata, Vol. 3, No.1 (2016):105-117.

Keller, Kevin Lane. Strategic Brand Management Building Measuring and Managing Brand Equity 4th edition. (2013). USA, Pearson Education.

Supriatna, Asep. "Relevansi Metode Participatory Rural Appraisal Dalam Mendukung Implementasi Undang-Undang Pemerintahan Desa". Jurnal Lingkar Widyaswara Edisi 1 No. 1 (Maret 2014):39-45. 